\title{
CHANGES IN ESTONIAN SCHOOL CALENDAR HOLIDAYS IN 1992-2018
}

\author{
Mare Kõiva \\ Department of Folkloristics, Estonian Literary Museum, Centre of Excellence in \\ Estonian Studies \\ e-mail:mare@folklore.ee
}

\author{
Kristina Muhu \\ Department of Folkloristics, Estonian Literary Museum, Centre of Excellence in \\ Estonian Studies \\ e-mail: kristina.muhu@folklore.ee
}

\begin{abstract}
The paper compares changes in the celebration of holidays in the period from 1992 to 2018. The data originate from large Estonian children's lore corpora from 1992, 2007, and 2018. The first collections are preserved at the Estonian Folklore Archives of the Estonian Literary Museum (ELM) in Tartu, Estonia, and the 2018 collection as well as the digitized data of the earlier campaigns are available in the digital archives EFITA - the Research Archives of the Department of Folkloristics of the ELM. The calendar corpus allows us to monitor changes in the structure and essence of folk/ ethnographic/local traditions, feasts celebrated at home, church feasts, and public holidays at school. The authors indicate that endeavours to establish national public holidays to accompany traditional agrarian ones began in the early $20^{\text {th }}$ century. During the $20^{\text {th }}$ century, the system of holidays changed three times $(1918,1940,1991)$ due to political changes: the establishment of an independent state in Estonia, the loss of independence and continuation as the Estonian Soviet Socialist Republic, and restoration of inde-
\end{abstract}


pendence in 1991. In addition to state, church, and folk holidays different ways to introduce novel international holidays (Valentine's Day, Mother's Day, Father's Day, Halloween, Mother Tongue Day), and a search for new forms of celebration were also noteworthy during this period. As students, youngsters participate in the celebrations of their school as well as in the celebrations of public holidays, and at the same time they are involved in maintaining their family traditions.

Keywords: Estonia, international feasts, Mother Tongue Day, national holidays, school feasts

\section{Introduction}

The feeling of cohesion that arises at school and in the classroom is also expressed in common holidays, which give a group-uniting and creative start; also, a close dialogue is essential in this development.

However, it is most important that children are the future adults, they choose the holidays they prefer to celebrate and decide which traditions to follow and which not. This is especially true in a situation where multi-ethnic and multitraditional holidays are added to the calendar. For example, the celebration of Valentine's Day at schools was initiated by teachers; the same applies to Mother's Day and some other holidays (Kõiva 2004; Vesik 2015). The period under study is long enough and enables us to generalize the changes related to holiday celebrations within this institution.

At the same time, the school calendar is also interesting for other aspects, such as a dialogue between teachers and students, in which the latter plays a significant role in shaping a holiday or a festival. In this respect, it is more than important to monitor the youth's calendar practices and the trends that emerge in them.

Unlike anthropology and sociology, folkloristics has long traditions in the studies of children's lore, especially as concerns individual genres, yet great differences can be detected by countries and domains. So far, very little attention has been paid to the school calendar, except within the framework of a study prepared by the SIEF Ritual Year Working Group (Gergova 2013; Hugoson 2013; Kõiva 2004; Vesik 2016), and the investigations of Estonian children's lore group (Kõiva 1995a, 1996, 2000, 2014; Kalmre 2003, 2010; Voolaid 2006). However, a wider interest has sprung up recently, especially with the emergence 
of multicultural issues in several areas (Niemi et al. 2019). Although the number of studies has increased, it is still necessary to investigate the growing interest in economic and social issues, such as father-to-son business models, as well as cultural diversity or unequal opportunities for migrant children, or language and children (Riley \& Paugh 2019).

One of the reasons for the lack of research interest may lies in its institutional nature, as less attention has generally been paid to this aspect when it comes to celebrating the ritual year. The reason may be that children live with their parents and depend on their funding; that is, they do not form a clearcut self. American anthropologist Lawrence Hirschenfeld (2008, 2013; see also Hardmann 2001), who assumes the interdisciplinary approach, links the underrepresentation of children's topics with an interest in the adults' sociocultural way of living: there is a clear stratification in the wealth and social relations and other circumstances among adults, while children represent a different self-organization.

Secondary, i.e. high school education has been normative until recently, but during the terms of office of the last few ministers of education there has been a strong pressure for the students to continue in vocational schools after the $9^{\text {th }}$ grade. Reforms in recent years have also led to the re-integration of schools into larger ones (a similar campaign took place in the 1960s-1970s) and the pressure to close smaller rural schools, leading to the early migration of children to cities, living away from the family or commuting daily. The school reform, on the other hand, also speeds up the migration of parents to larger centres.

The schoolchildren's calendar is characterized by several special features: as students, children participate in the celebrations of their school as well as in the celebration of public holidays, and at the same time they are involved in maintaining their family traditions. School education covers 12 years, between the ages of 7 and 19, which have a decisive role in the life of an individual. The major ideas of the specific features of school celebrations are the following: maturing of the children and building the system of values; the feeling of cohesion in the school; the role of the institution and the pupils themselves in transforming the ritual year. During these years the child develops into a young adult, matures physically, and becomes a personality. As a person, they define their position in the classroom and at school, as well as in attitudes to the events taking place during the ritual year. Educational institutions have a major role to play in nurturing values (new or basic values), but/and they also emphasize remembering the past. 
The degree of independence given to students varies by schools. However, from 1990 each school has a student representation who mediate students' stances; also, event organization is increasingly delegated to students. Earlier on, it was mainly limited to organizing Teachers' Day and partly also Christmas's party and graduation events. As to holiday celebrations, schools are given a free hand, and already in 2004 a connection could be detected between creative teachers and the diversity of events (Kõiva 2004). The increasing number of private schools has added to the variety. On the other hand, greater freedom has shifted the teacher as a personality to the responsibility position. Liberalization of the ways of celebration is manifested in the comments made by Kristiina Punga, our cooperation partner, history teacher, and one of the organizers of students' humanities conference HUNTS, regarding the collection results:

It seems to me as if the picture is getting more and more diverse. The beginning of the school year is a good example: there are schools that start on a Monday, no festive meeting is obligatory, and the end of the school year is even more different - as class record books are electronic, no manual reports are given. EFITA, F01-021-006-0002

It is significant that Russian schools in Estonia celebrate the same holidays as Estonian ones, ${ }^{1}$ including folk calendar holidays, yet this is a topic for a further research. Church holidays are celebrated according to Lutheran traditions, although congregations are rather small in all confessions in Estonia. This signifies, above all, historical continuity, as Estonia has been a Lutheran country since the beginning of the 16th century. On the other hand, Orthodox, Catholic, and other holidays are also allowed to be celebrated. The article discusses how two factors - changes in political systems and global trends - affect the celebration and feast transmission in the Estonian school community. A synthetic view of the current and recent trends in the Estonian school calendar and of the transmission of traditions are presented, based on both statistical and qualitative information derived from recent collections, studies, and surveys.

\section{Data and Their Limitations}

From 1920 to 1944, schoolchildren were engaged in conducting surveys across the country, and the role of students was either to capture the knowledge of 
older people or to write down their own folklore circulating among children. For instance, a large-scale campaign of gathering calendar traditions was associated with M. J. Eisen's interest in spring holidays (Easter) and Christmas customs; he used the responses to gain a deeper insight into areas where adult responses were sparse (cf Eisen 1931). Oskar Loorits was interested in the relationships between mythological creatures and children's bogies, which initiated him to launch a massive-scale collection campaign concerned with children's bogies, involving all Estonian schools; he used the results in his scholarly work (Loorits 1949).

The goal of the grand collection of children's lore, attempted in 1992, was to get as diverse an overview of children's lore and customs as possible at that time and to find the causes, directions, and areas of the rapid change. It was not an order or a project financed by someone, but an inevitability perceived by folklorists from different institutions, a necessity to examine the state of the old patterns and to find the current ones. The first collection competition was organized in cooperation with Ulla Lipponen, folklorist from the Finnish Literature Society ${ }^{2}$ (about the results see Kõiva 1995b; Hiiemäe 2002; Kalmre 1995).

In order to get a longitudinal overview, the survey was repeated in 2007 . The survey resulted in the first-ever description of several phenomena, including a novel view on fears, pet-related themes, nicknames (cf. the survey by Voolaid 2007). Regarding the calendar, the aim was to record holidays throughout the year, to collect data on the name-day tradition, to record birthday traditions, and to document student holidays. Two answering methods were used: either on paper to be posted individually or as a member of a class (in case the whole class participated) or by using the online forms.

In 2018, the process of collecting the school and children's lore took place mostly by using online forms, and only a few schools and a few students sent written answers on paper. The selection of schools also changed to a certain extent - extensive urbanization was considered, and therefore more schools in Tallinn and Tartu were included in the pool; some rural schools had been closed down or had been converted from secondary to basic schools.

In terms of numbers, in 1992 the participation was as follows: 1,797 students submitted 27,000 pages of answers, and folklorists in several regions additionally recorded data (in Narva, Tartu, Valga, Ahja, and Kõrveküla, Kõiva 1995a; statistics in Kalmre 1995). In 2007 the respective figures were 2,800 students and 15,000 pages (Voolaid 2007), and in 2018 approx. 3,700 students answered mostly online (Hiiemäe 2019). 
The collected data have some limitations. As the questions were open-ended and there were no prelisted choices, the students enumerated memorable holidays rather than described them in more detail. The answers were also limited by the number of themes asked (in this case the calendar was located relatively at the end of the survey: $1992-9^{\text {th }}$ place, $2007-5^{\text {th }}$ place, $2018-5^{\text {th }}$ place. When filling in a long survey, considerable answering fatigue occurs towards the end and answers become shorter. The placement of the questions in the survey correlates with the number and quality of the answers; therefore, the answers to the first and second blocks of questions were more in-depth.

For example, the 2018 survey is characterized by the following numerical values:

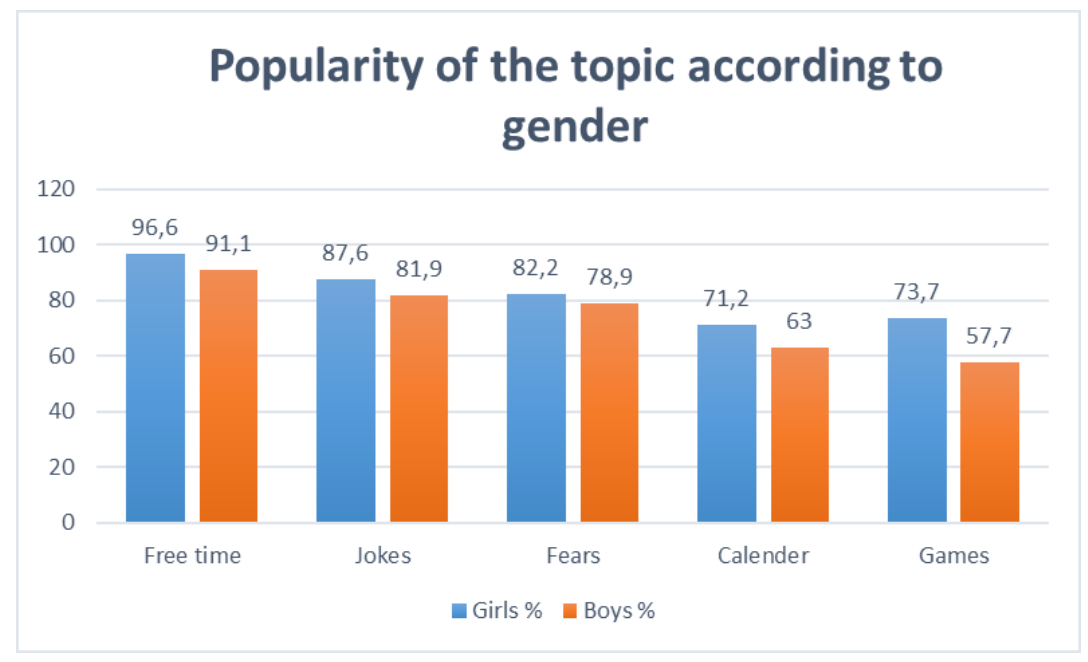

Figure 1. Popularity of topics according to gender.

Age-specific differences are also quite visible: the children we interviewed were $4^{\text {th }}$ to $12^{\text {th }}$-grade students, i.e., between the ages of ten and eighteen-nineteen years of age, and, correspondingly, they had a different role in holidays. The best respondents were $6^{\text {th }}$ to $9^{\text {th }}$-grade students with good observations and fluent self-expression. 


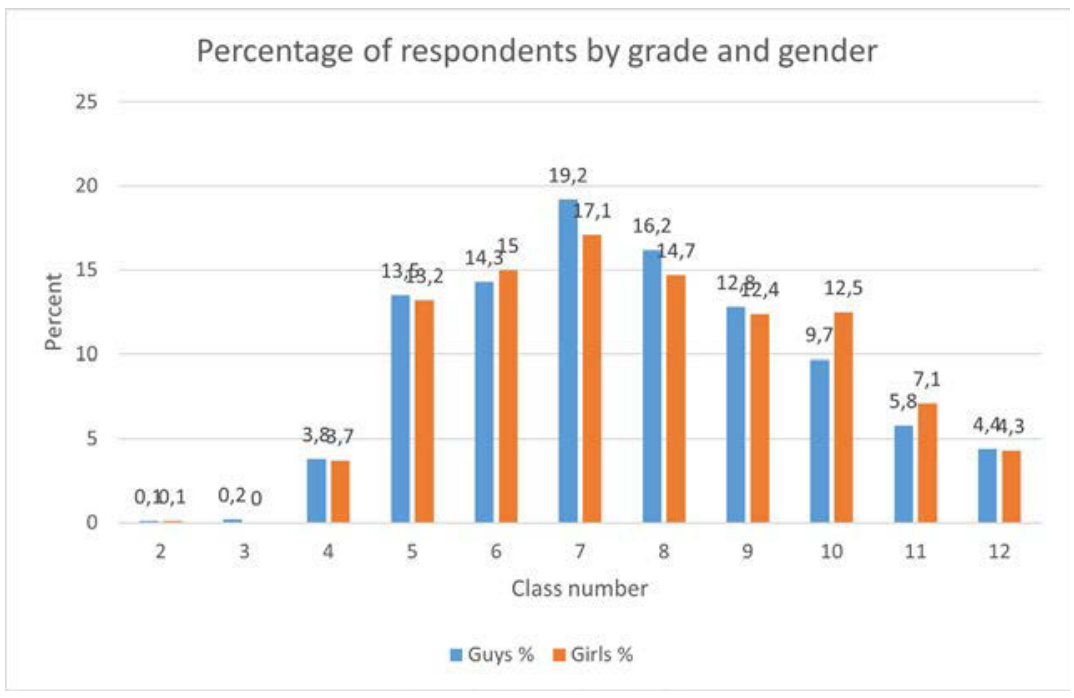

Figure 2. Percentage of respondents by grade and gender.

In the 1960s, the problems of authenticity and relevance arose acutely: closeness to publications was considered as a not folkloric phenomenon and attitude to the mixed forms of dissemination was negative. ${ }^{3}$ Children's writings were also considered with reservations: this attitude might have been caused by the model of an irresponsible child. The authors of this article opine that answers proceed from the skills of the person who asks them as well as children's stances and represent their viewpoints. The most recent sociological polls indicate that children's estimations can differ from adults' models and represent independent models; yet, they cannot be regarded as inadequate (Reinomägi 2020).

\section{General Trends}

Public holidays, including those celebrated at school, have changed three times in the $20^{\text {th }}$ century: in 1918,1945 , and 1991 . As the national holiday system develops over the years, the final version of public holidays had been established 
in Estonia by 1937 (the Republic of Estonia was established in 1918, which indicates that the formation of the calendar system was a longer process). In 1940-1990, Estonia (under the name of the Estonian SSR) was part of the USSR, the public feasts were reorganized several times during the post-war period (about feasts see Kõiva 2014; Kreegipuu 2011: 70). Also, during re-established independence, the system of state and national holidays was reformed in 1990, 1994, 1998, and 2009. This indicates that the stabilization of the holiday cycle has been a long and dynamic process. As in the early 1990s the holiday system was still taking shape, the questions in the first survey were concerned with new holidays, such as Valentine's Day, Halloween, St. Patrick's Day, as well as with students' own initiative in organizing holidays.

It should be noted as a peculiarity that in the period 1990-2004 schools were relatively free in their choices of celebrations. Among the permanent holidays were: 1 September (now Wisdom Day), Teachers' Day (International Teachers' Day), student initiation ceremony (hazing), Father's Day, St Martin's Day (and St. Catherine's Day), Christmas, Valentine's Day, Mother Tongue Day, Shrovetide, Easter, Independence Day, St. George's Day, Mother's Day, the Last School Bell, one-hundred-days ball, and graduation celebration. Dozens of holidays in different schools were characteristic of a particular school (medieval-style May Day at Leie School, St. Lucia's Day and Kingdom Day at Noarootsi Upper Secondary School). To sum up, school-specific starting and ending celebrations, the most well-known church and folk holidays (Christmas, Easter) dominated (Kõiva 2004; Vesik 2016).

In 2007, about a third of the respondents answered questions about calendar holidays (968 students from the total of 2,800), and 62 percent of them were girls. The answers show that there are more calendar holidays among the most popular events than entertaining events and dance parties. The most popular were Christmas celebrations, Valentine's Day, Shrove Tuesday, St George's Day, St. Martin's Day, St. Catherine's Day, and Ribbon Bow Day. The rest of the holidays enjoyed less popularity.

The results of the 2018 survey were as follows. The most popular were Christmas (incl. Advent), Friend's Day or Valentine's Day, St. Martin's Day and St. Catherine's Day (the last two feature masking and visiting homes, asking for gifts), yet the rising position of Halloween, also related to masking, is noticeable. Shrove Tuesday has surprisingly lost its status as a favourite. 


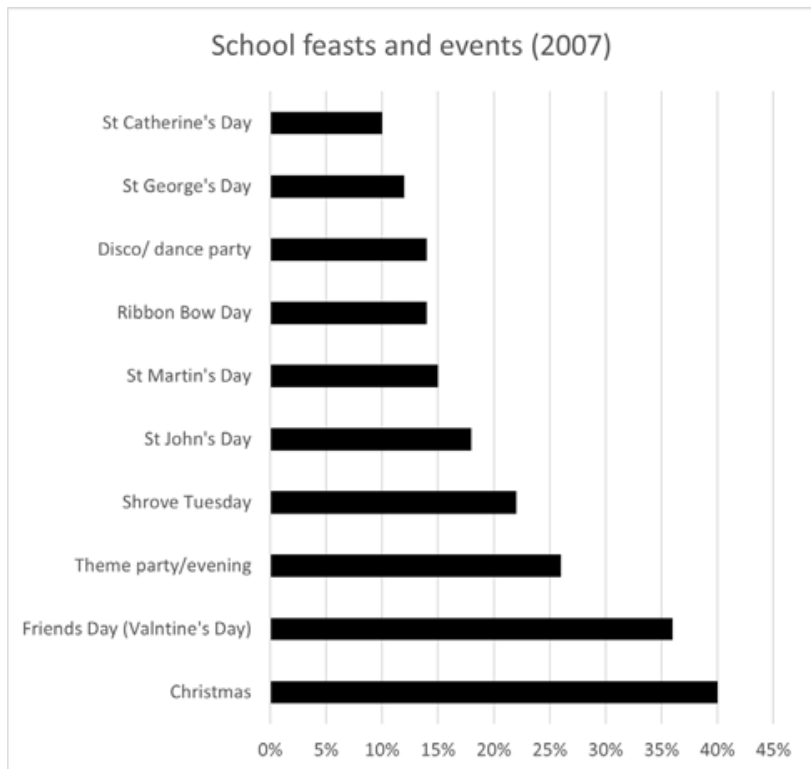

Figure 3 . The most popular events during the 2007/2008 schoolyear.

\section{School feasts and events}

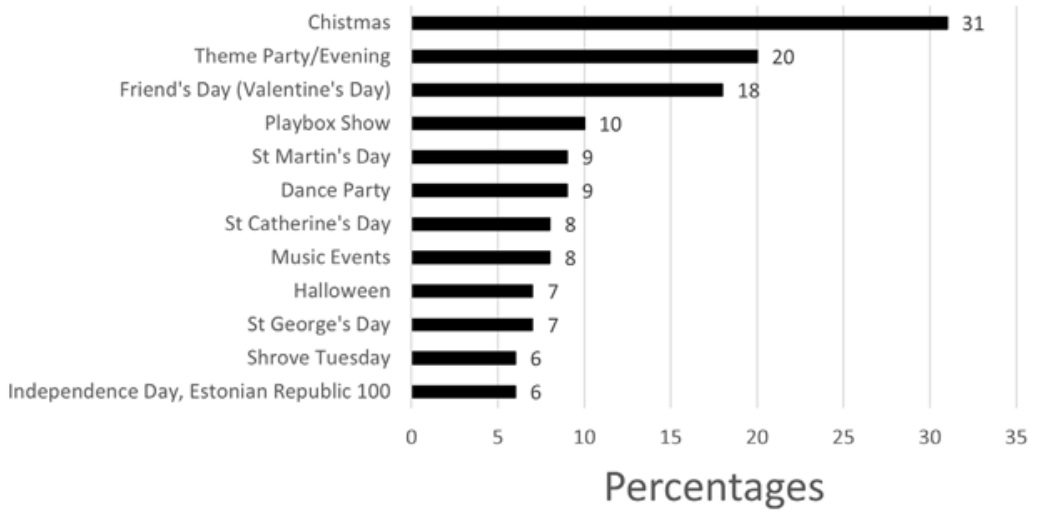

Figure 4. The most popular events during the 2018/2019 schoolyear. 
Style parties (and evenings), playbox shows, music and song events, dancerelated events (disco, ball), fashion shows and talent evenings, carnival and sports events were mentioned among school holidays and events, as well as imitations of the popular TV show "Your Face Sounds Familiar" ("Stars in Their Eyes" in the UK).

Below is an overview of the role of school in organizing events during the school year:

Our school celebrates anniversaries a lot. On St. Michael's Day, there is St. Michael's Fair, for which all those willing can make something at home and then sell it at the school fair. All students and teachers can buy what they want at the fair that day and so children can make money. On All Souls Day, people behave quieter than usual and light candles. On Martinmas, the younger students disguise themselves in different costumes and then come to the door of our class and sing: "Let the Martinmas mummers in.... We let them in, listen to the verses they have learned, and answer riddles that we don't usually know, but that is exactly their goal. Then we would give them candy and they would leave us with good wishes, for example, good grades, etc.

At Christmas, we have a festive Christmas concert, which is also attended by Santa Claus, with large bags of gifts. On Valentine's Day, everyone is friendly, and valentines (cards) are made for each other. We celebrate Shrovetide at school or go somewhere to ski or have a sled ride.

On Women's Day, flowers are given to girls and there are various activities for both girls and boys.

As part of Mother Tongue Day, we have a song and poetry competition called Leie Song and Poetry Bird, in which all those willing can take part by reading a poem or singing a song.

On April Fool's Day, we just play pranks.

On Mother's Day, we also have a concert, and, in addition, an exhibition of student handicraft completed during the year, which can be seen by not only mothers but also by all other interested people.

On St. George's Day, students are divided into teams in advance for a race, and members of each team take turns to complete a part of the course of the race. Of course, each team also has a torch, which is passed on like a baton. The winning team is the one who is the first to reach 
the finish line with a burning torch, and the traditional prize is a cake. I believe that everyone at our school is happy to take part in all the events. ID $3,587,9^{\text {th }}$ grade

\section{Church Holidays}

The celebration of church holidays at school was a complicated topic due to the establishment of Soviet power just before the Second World War. The progress of the reform is most adequately reflected in the then diaries and reminiscences. School was a special instrument in the dissemination of the new ideology and in 1940 all church holidays were deleted from the calendar, except for Christmas. The reason might have been the Estonian name jõulud (Yuletide), which probably misled the reformers. Immediately after 1945 Christmas also disappeared from the list of the public holidays (Kreegipuu 2011: 81). However, church holidays were still celebrated at people's homes during the Soviet period, and some of them were celebrated at schools shortly before Stalin's death in 1953 as old pre-Christian holidays: New Year's Eve (Est. näärid), St. Martin’s Day (mardipäev), St. Catherine's Day (kadripäev), St. John's Day (jaanipäev), St. George's Day (jüripäev). As the Lutheran tradition does not celebrate saints' days, popular messages and celebration customs remained in the foreground. In the past centuries, for example, St. Martin's Day and St. Catherine's Day were holidays related to livestock and grain farming, and were known for masking customs, except for the Orthodox south-eastern Estonia inhabited by Setos. St. George's Day marked the beginning of livestock herding as well as preventive magic; yet it was also associated with Estonians' uprising against the Livonian Order on 23 April 1343, as the message was compatible with the new ideology.

Christmas was also associated with the old holiday cycle, which began with St. Thomas' Day and ended with the Epiphany (Tedre 1969: 76). Although the Christmas cycle was not officially restored, disguises such as Christmas geese, Christmas bucks and other traditional elements of customs in western Estonia and on the islands were part of the school's cultural tradition and local features.

When we explored the school festivals, the biggest changes (in the years 1992-2018) we expected to detect were in connection with the anniversaries of the church calendar, the celebration of which was now free and legal and did not depend on the goodwill of the headmaster or teachers. 
Public religious holidays include Good Friday, Easter Sunday, the first day of Pentecost, Christmas Eve, and the first and second day of Christmas. However, we discovered that there have been no major changes in this area in the past 30 years, apart from school choirs' Christmas concerts in churches. But let us turn to our expert again:

Pre-Christmas festivities are also mostly joyful. For a long time, many schools had common church services, yet this tradition seems to be fading gradually. Parties are organized in schools or by classes, and more and more often presents are not given anymore. EFITA, F01-021-006-0002

This is also confirmed by the data of the 2007 school lore campaign: some classes donate the money collected for presents to animal protection societies or charity organizations. ${ }^{4}$

Students demonstrated the warmest feelings towards Christmas parties, because they also appreciate the opportunity to create a witty show and have a great time. They like Christmas as one of the holidays which are most reasonable to celebrate at school by age groups, as each of them has their age-appropriate customs, traditions, and jokes.

The Catholic schools in northern and southern Estonia have sought to add Catholic anniversaries, as, for example, St Lucia's Day in Tartu and Tallinn. ${ }^{5}$ If we add to the 2018 survey results, for example, the results of a student survey published in the newsletter "Prophet" of the Tartu Catholic Education Centre, students preferred as performers for their Christmas party either the academic brass band Popsid from the University of Tartu or the university alumni. Things considered important were the election of the ball king and queen, joint and round dances, conjuring tricks, and Father Christmas; also activities involving all the students were emphasized, as well as bringing, for example, animals (alpacas, reindeer, lamas) to the ball room (Vaher 2019).

In the middle of the $19^{\text {th }}$ century, Orthodox congregations emerged in connection with religious conversion. The Estonian independent Orthodox Church was established during the Republic of Estonia in 1918; it was subordinated to Constantinople in 1923, and switched over to the new calendar in 1920s, whereas the churches subordinated to Moscow continued to use the old calendar (in more detail see Papathomas \& Palli \& Matthias 2002). Of greatest success have been Orthodox holidays, which were celebrated locally throughout the Soviet era, including St. George’s Day (May 6) in Värska and St. Paraskeva’s Day 
(July 20) in Saatse, south-eastern Estonia, when people travel back from all over Estonia to celebrate. Orthodox regional holidays have kept their significance; they are important festivals because people originating from that region come together for that day. After visiting church and joining the procession, Orthodox families lay food on the graves of their dead and have a meal there. In the evening people have kirmas $(k)$ - a celebration with traditional folk songs and dances. There are no celebrations at the local school, yet the school encourages joining one's family for the festivities.

I live in Setomaa; we celebrate St. Paraskeva's Day (the day of remembering the dead). We (my parents, other relatives, and I) gathered around the grave of our relative in Saatse village. We were eating together and walking in procession around the church. ID 373, Värska, $8^{\text {th }}$ grade

In other areas, village or parish days with a package of cultural events (dances, songs, a fair of local food and handicrafts) are common, yet they have looser connections with the school calendar.

Visiting relatives during holidays has been a continuing problem since many people have moved to the city or started work in other places. There are, as it were, two possibilities - to try to visit all relatives during the holidays, or to decide where to go for which holiday.

One way or another, there are two central holidays - Christmas and Midsummer Day, when the family reunion is most important, as is making a Midsummer bonfire if possible. It is in the case of these two holidays that human warmth and mutual care are most manifest, and people cherish the customs of their own family, which are similar to general customs but have a special undertone in each household.

\section{State Holidays}

Some Baltic researchers (Vaiškunas 2013; Šaknys 2015; Mardosa 2016; Paukštytė-Šaknienė 2018; Kõiva 2014) have demonstrated what happened to the church and state holiday cycle introduced in the period from 1929 to 1944 and during the Soviet era, and how holidays were re-established in 1990 and later on. In Estonia, the following anniversaries started to be celebrated in connection with gaining independence: Independence Day, the Treaty of Tartu, ${ }^{6}$ and 
Victory Day. ${ }^{7}$ The first step taken by the new political power was to replace the anniversaries of statehood and history in the calendar with Soviet holidays: the anniversary of the October Revolution (7 November, celebrated in the USSR from 1927 until 1990), and the Constitution Day (5 December, celebrated from 1924, changed in 1937; in Estonia in 1947-1990). After the Second World War, Victory Day (anniversary of the Victory in the Great Patriotic War) was added, which was a day off. ${ }^{8}$ Beginning in the 1990s, Europe Day marking peace and unity in Europe is celebrated on 9 May, yet it is an ordinary working day.

The Tartu Peace Treaty is an ordinary working day (but valued highly in society), which have a fixed structure.

The Tartu Peace Treaty was signed between Estonia and Soviet Russia in Tartu on 2 February 1920, and it ended the Estonian War of Independence and determined the eastern border of Estonia as Soviet Russia recognized the independence of the Estonian state. In Tartu, the celebration sticks to a fairly solid structure. The day starts at $10 \mathrm{am}$ with a commemorative event for Tartu secondary schools, which takes place at Jaan Poska Gymnasium in Vanemuise Street. The welcome speech of the Mayor of Tartu is followed by a speech by a representative of the military, and a performance by a brass orchestra and a folk-dance group. At the same time, the representatives of the city council lay wreaths at the War of Independence Memorial in St. Paul's Cemetery, at the war hero Kuperjanov's grave in Raadi Cemetery, as well as at the Monument to the Liberators of southern Estonia and the Kalevipoeg ${ }^{9}$ Monument in Tartu.

Later on a ceremony to commemorate the Tartu Peace Treaty begins at the Kalevipoeg Statue of Liberty in Tartu, where the Mayor of Tartu, the head of the Estonian National Defence College, the Chairman of the Tartu City Council, and a representative of the student corporation Fraternitas Liviensis alumni speaks. This concludes an important part of the public celebration. After that, those interested in history are welcome to the Tartu City Museum, which introduces a display about Tartu and the War of Independence, the fate of Tartu during the War of Independence, the occupation of Tartu and its liberation from the Bol'shevik (Red) Army, the progress of peace negotiations, and other topics.

The anniversary of the Tartu Peace Treaty is celebrated at schools in different ways, and it is one of the ways to honour local veterans of the War of Independence and recall history.

As several Estonian towns, including Pärnu, played an important role in the proclamation of the Republic of Estonia, the commemoration ceremonies 
are more solemn than usual in those places. For example, some events take place in Pärnu Alevi Cemetery, and the anniversary of the Tartu Peace Treaty is celebrated at Sindi School. Some people celebrate the day with a more festive meal at home.

\section{Independence Days - 24 February, 20 August}

While 24 February is celebrated nationally and at home, the celebration of 20 August - Independence Restoration Day - is less rooted. On 23 February 1918, the Manifesto to All Peoples of Estonia, read out publicly in Pärnu, declared Estonia an independent and democratic republic. On 24 February, the manifesto was printed in Tallinn. On 8 May 1990, on the last day of its existence, the Supreme Soviet of the Estonian SSR declared the Estonian Soviet Socialist Republic invalid and the Republic of Estonia was re-established.

The expert-teacher comments:

I tend to think that the anniversary of the republic is celebrated at schools; no ceremonial meetings are obligatory, yet they are held at many schools; it is discussed at history classes, the schoolhouse is decorated, and often speech contests or sports events are organized. The situation has obviously changed because now school holidays are also in February. On the one hand, it is a great possibility to link the end of the half-term with festivities; on the other hand-24 February used to be the only day off in the past, and therefore could even deserve more attention. EFITA, F01-021-006-0002

24 February is usually celebrated with fireworks, concerts, parades, and parties as an Estonian national day. As it is a public holiday and a day off, it is possible to join public concerts, enjoy a stroll with the family in the city or spend time watching TV and eating a festive meal (cf. Lithuanian traditions in Mardosa 2016: 120-121). Many families watch the president's reception on TV to see the attendees' glamorous costumes and comment on the party, which is traditionally called a 'penguins' parade'. As a counterbalance to the celebration of the creme-de-la-creme of society, a procession with torches through historic Tallinn has become a customary event; it is joined by young and old, in a common celebration of the birth of the republic. 
The independence and re-independence of the Republic of Estonia - we celebrate them, it means that we have festive meal, board games, watching the parade and the reception, watching patriotic films, decorating the home. ID $2408 \mathrm{Tartu}, 8^{\text {th }}$ grade

\section{Reinvented and New}

Mother's Day (the second Sunday in May, introduced in the United States in 1908; in Estonia its meaning was conveyed with some local adaptations in the 1920s) is a good example of holidays that began to be celebrated during the Republic of Estonia and were reintroduced in the 1990s. In the 1920s-1930s, a plan for the promotion of the celebration of Mother's Day, and sample plans for celebration by schools were developed by Women's Home Defence societies and other organizations. Mother's Day was successfully confirmed as one of the most important national holidays; it was introduced at schools and its celebration at home was strongly inspired (Õunapuu 2001; Kõiva 2014). The 2018 answers reflect that celebrating Mother's Day at school is a norm and it is also celebrated at home, in the family circle.

The International Women's Day (8 March), however, has made an interesting resurgence. It disappeared from the list of public holidays and holidays in general in 1990, but has become more and more remembered in the family circle and also celebrated at the school; its celebration is not officially regulated, and in a sense Mother's Day and Women's Day have changed places. State media has also started to mention Women's Day again.

Father's Day (the second Sunday in November; Finland, Iceland, Norway, and Sweden also celebrate it on this day) is being launched with the full force of the media, and some progress has been made at schools: competitions and celebrations are organized with fathers, surprises and gifts are recommended for them. Father's Day at school is mainly celebrated with competitions, and fathers are invited to participate. The creation of a more festive atmosphere at home is also encouraged in every way.

Mother Tongue Day (March 14) is among the newest holidays that were introduced in the 1990s, and it is celebrated at schools. The only Estonian national holiday related to written and oral language was established on the 
birthday of the poet Kristjan Jaak Peterson (1801-1822) in 1996. Meinhard Laks, a schoolteacher and linguist from Sonda, north-eastern Estonia, was one of those who initiated such a special language day. After several attempts, the holiday was approved by the Parliament. The forerunners of Mother Tongue Day were the Language and Folklore Days organized as a joint event of schools and the Mother Tongue Society. This was a unique opportunity for students to meet famous linguists, but also literary scholars, folklorists, and writers. Since 1999, Mother Tongue Day has been a national holiday, celebrated by schools and cultural organizations throughout Estonia. In addition to guest presentations, thematic days are important as they give students an opportunity to present their research work and poetry, and one of the aims is to motivate students' performances and create a better connection with the language. The equivalent of Mother Tongue Day is the International Mother Language Day proclaimed by UNESCO in 1999 to be observed on 21 February.

Mother Tongue Day - a festive event / concert where students can read their own poetry, for example. ID $1369,9^{\text {th }}$ grade

Valentine's Day and Halloween spread in the ritual year as early as the 1980s. L. Vesik points out in her research (2016) that the main aim of Valentine's Day celebration is not love but rather the strengthening of friendships. The temporary post boxes with friendship messages and the special atmosphere make the holiday interesting for most children, though we have also found those who are against this day and say they hate it. Halloween is more known as a partying event, but it is popular because it entails joy and fun:

Then, on Valentine's Day, everyone gets a half of the paper heart with a number at the school entrance, and the task is to find a heart with the same number. Anyone who finds their match from the whole school will get a gift.

During Halloween, we are allowed to come to school in scary clothes, and then there are competitions organized by the student council. ID 991, $8^{\text {th }}$ grade 


\title{
Mare Kõiva, Kristina Muhu
}

\begin{abstract}
A. Kirjelda celmisel ja sel aastal koolis tähistatud tähtpäevi (nt mardipãev, jüripäev). Millistel üritustel ja tähtpäevadel osaletakse
\end{abstract} koolis meelsasti?

\footnotetext{
Valentinipāicya (Söhrapăeva) tahistatakse meil iga aasta. Sel aastal oli kóik văga hästi organisceritud. Trepil ootasid inimesi punaste seidametega opilased, kes nputasid neid südameid teistele kaela. Igale südamele oli kırjutatud mingi nimi. Pacva jooksul sai sopradega enda ja teiste nimede ale naerda. Toimus ka kalliteenus, mis kujutas endast seda, ct vöisid 2 krooni eest tellida kelielezi koolist kalli ühe valentinipàcra „maskoti" poolt, ethk siis Joomakostüinmis ringi jecksvalt komaldajalt. Teimus ka loterii ja sỏbralikuma opetaja valimine: Risetuskood oli punane ja valge, mida ka paljud jargisid. Uldiselt văga positiivne ja tore pàev'
}
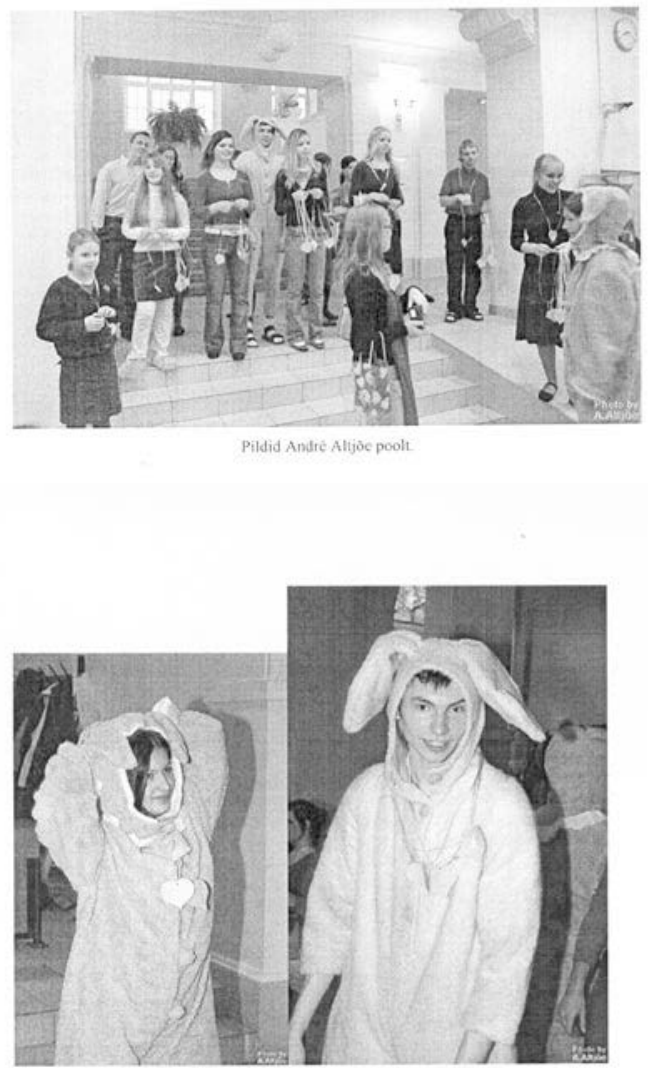

Piltidel on naha treppide ces inimesi südameid jagamas ning maskotte loomakostüumides.

Figures 5 \& 6 . Friend's Day (St. Valentin's Day) in Tallinn English Col-

Meie koolis korraldatakse ka spordipaevasid. Neid tavaliselt üks veerandi kohta, kus siis lege in 2007. Photopühendatakse terve päev spordile. Tuüpilised tegevused spordipàeval on klassidevaheline graphs by André Altjõe. 


\section{Joy and fun}

April Fool's Day - 1 April - is a permanent component of the school calendar, which is celebrated by playing pranks both by adults and by children at school, with jokes aimed at fellow students and, if possible, also at teachers. Most students find the day to be fun and this is definitely the reason why the celebration of 1 April has persisted (about jokes and proverbs see Voolaid 2020; Kõiva 2004).

Improvisational events vary considerably, with schools showing great initiative. Entertaining elements intertwine with the opportunity to be with peers in slightly uncomfortable conditions; for example, staying overnight in sleeping bags in the school hall. This little excitement is indirectly reminiscent of hiking and camping. There are also some other ways to make the school life more interesting, such as karaoke, balls, concerts, performances, quizzes, etc. Here are some examples of fun activities at school:

I enjoy participating in Playback shows, where one general topic is given, and every class has to do it (I perform a lot outside of school). ID 119, $9^{\text {th }}$ grade

When talking about holidays, it is impossible not to mention a unique event at our school called "Dark night party". It takes place once a year and gives a chance to stay at school overnight. If you want to take part in a disco, karaoke, games, horror movies, then you have to make a playback. To stay at the dark night party requires performing from you. This party is one of the best events at our school. ID $3480,9^{\text {th }}$ grade

\section{Changes in 1992-2018}

Today, calendar holidays are proposed and established by various secular headquarters; several international organizations (UN, UNESCO), initiative groups, etc., have the power to declare international or global anniversaries, days, feasts. Thus, the year-round cycle is covered with important days of remembrance and dedication, and the role of the school is to help navigate in all this abundance. 
The socialization of schoolchildren takes place across a wide range of culturally salient settings, including home, school, fan and hobby groups, and in many more places and environments, where they learn and experience the essence of culture. There are several differences in the material from 1992 to 2018: on the one hand, the decision-making power of the students increased; on the other hand, there were so many events that many respondents manifested no desire to take part in non-compulsory events at school.

Jan Assmann has drawn attention to feasts and rituals, which - through their repetition - ensure the reproduction of cultural identity (Assman 2011: $27 \mathrm{ff}$.). Ritual recurrence, writes Assmann, provides coherence to a group in space and time.

The feasts of the ritual year in school are associated with several influences: a) National anniversaries, victory and remembrance days, celebration of the founding/first mention of the state are of major importance;

b) The second basic structure is presented as a link between church feasts and family traditions (Easter, Pentecost, Christmas/Yuletide). It includes universal, local holidays and holy days, church name days, in Christian Orthodox regions also St. Paraskeva's Day and St. George's Day;

c) Celebration of kinship and tribal relations, as Mother's Day, Father's Day, St. John's Day;

d) Anniversaries of corporations and professions: International Teacher's Day, Wisdom Day (1 September);

e) Celebrations conveying humane values: the Earth Day, tree planting, etc.

Undoubtedly, statehood exerts the biggest influence on the national calendar, which fixes big anniversaries and, in some cases, smaller occasions. Despite the short period, it is possible to see restoration models: as the statehood continued, the holidays of the previous republic were restored (24 February - Independence Day, 24 June - Victory Day, 2 February - anniversary of the Tartu Peace Treaty). The new anniversaries related to the birth of the national state were added: 20 August - Independence Restoration Day, and 23 April - Veterans' Day (was added on St. George's Day in 2013). With some delay, 1 May was added as a spring holiday (Spring Day) instead of the International Workers' Day (or Labour Day), which had been celebrated throughout the $20^{\text {th }}$ century; currently these are not marked in the school calendar. 


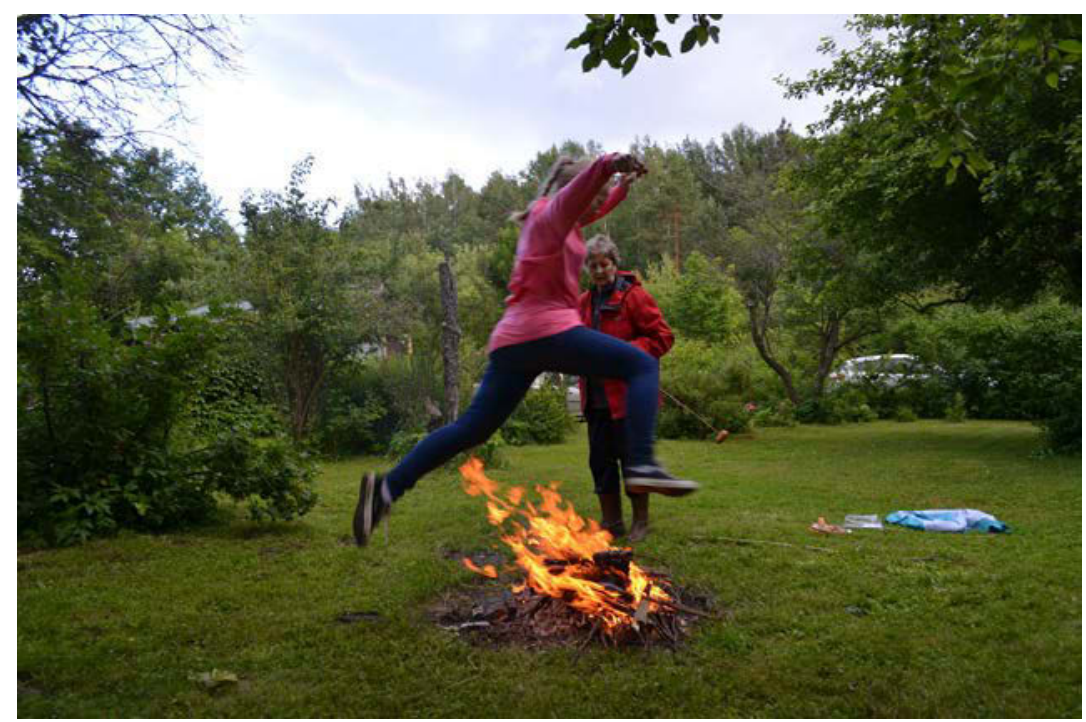

Figure 7. St. John's Day in Märja. Old customs live in city. Photograph by Piret Voolaid 2018.

From the older calendar holidays, part of schools celebrate St. Martin's Day and St. Catherine's Day; also, on the initiative of schools, All Souls Day, Shrovetide, St. Michael's Day, and St. George's Day. During the Soviet period the latter became known as the Torch Run and as such belongs to the national narrative as a day of remembrance of the 1343 uprising. On St. Martin's Day and St. Catherine's Day small groups of mummers move around, although urban conditions do not particularly favour it. The expert estimate helps to explain why several holidays popular in 2007 have today disappeared in the responses of schoolchildren:

Easter is maybe marked somehow in basic schools; I haven't heard of any particular event related to it. As it is a moving holiday, it has not found a place in the school calendar. And I must admit that although Christmas tradition persisted throughout the Soviet period, several past generations have been estranged from Easter. EFITA, F01-021-006-0002 
Estonian school celebrations are not strained by religious or national confrontations. In Orthodox regions keeping to the old calendar system, people continued celebrating their more important holidays, and these became symbols of local identity, which were adapted to the city culture or when moving farther away from the home community (Kõiva 2006). The survey indicates that some holidays are continued on an informal basis; for example, the return of Women's Day after a period of its denial.

Also, the mass deportation days on 25 March (1941) and 14 June $^{10}$ (1949) are commemorated by a group of people, mostly the victims and their relatives. As institutionally the complicated and humanely difficult periods in history are not publicly discussed, leaving the explanations to volunteers and teachers, this situation results in misunderstandings and constitutes a source for further tension.

Paying attention to history or cultural history events depends on the teachers' initiative. There are definitely schools in which something is done in connection with the March deportation (in our school, for example, in the history circle); the June deportation remains within the summer holidays. At some point, schools were ordered to do something to mark the Holocaust Day, yet it found strong resistance and the ministry sent no more directives. EFITA, F01-021-006-0002

The same applies to taking flowers to the monument of the Second World War at the military cemetery in Tallinn on 9 May. Those who do it are small groups of Russian schoolchildren, who wear military uniforms with St. George's ribbon; sometimes they go with families. These celebrations have not resulted in conflicts, yet they refer to neglected problems and ignoring of human memory and sufferings. As there is no local alternative to celebrating the anniversary of the end of the Second World War, celebration models from Russia are taken over in the capital city, but also in Russian villages in eastern Estonia (about tendencies in Russia see in more detail in Titkov 2019: 206 ff., in Estonia in Loit et al. 2020: 310-314).

When analysing schools' websites after the survey, it could be seen that teachers as personalities and preservers of school traditions were responsible for not only most important remembrance days and a number of church holidays, but also for the traditional holidays in the folk calendar, which in high school disappear from the list of events celebrated at school also in the remote areas. 
This places great responsibility on the shoulders of nursery and primary school teachers as well as families. However, there are also examples of continuing celebrations if need be. A good example is $8 \mathrm{March}$, which is becoming more and more visible in the private and public space.

Students' responses reveal information about the old tradition - Easter, Pentecost, Yuletide, Midsummer Eve. Masking on St. Martin's and St. Catherine's Day has been preserved, and masking traditions on the islands around New Year have been revived, although a major part of them are celebrated outside of school.

The data show that students value family holidays more than school holidays. According to the data of 2018, the most appreciated was Midsummer Eve (June 23), which was considered the best holiday by 50 percent of the respondents, followed by Christmas (44 percent of the respondents), which ranked higher than personal birthday. Some of the most mentioned holidays included New Year's Eve (11 percent) and Easter.

With my family we celebrate Christmas, Easter, the anniversary of the Republic of Estonia, Midsummer Eve.

On Midsummer Eve we gather with relatives to have a great time together. Since we live in different parts of Estonia, it is nice to meet during holidays. Children play together and I usually supervise them, since I have done a course in animation. Sometimes adults also play games, but mostly on their own and so it is. We also prepare food together and after eating we still sit together at a large family table. We always take lots of great photos to remember this day. ID $2408,8^{\text {th }}$ grade

Midsummer Eve. We have a large family. Usually on Midsummer Eve we go to the countryside, to my grandmother, where many relatives gather. There we grill, go swimming and to sauna, look for fireflies. We also dance at every party. Most of them are classical dances, such as waltz and polka. But folk dances and social dances are also planned. We also do family games and competitions. ID $1369,9^{\text {th }}$ grade

The 2018 survey demonstrated educational mobility - attending a city school from the countryside, as some city schools have a higher reputation. The closure of some local schools led children from smaller places to join schools away 
from home, based on competition - the beginning of a kind of chain migration; at the same time, children from a certain region prefer to go to the same city school. For example, the 2018 survey revealed the movement of children from Põlva (south-eastern Estonia) to Hugo Treffner Gymnasium in Tartu. Migration led to the movement of different knowledge, attitudes, worldviews, and values, and stimulated student activity. Several topics within the 2018 survey demonstrated that students have considerable experience of the way of life in a village or a small town, where they return for the weekend, and to which they mediate different customs and traditions from the urban space.

Children's active contribution to holidays varies with age, and their observations are largely age-appropriate. Within the family, children are not allowed to attend some events where they are not expected or where they are restricted participants - they have their own games and activities; for example, at weddings and Christmas celebrations, whereas they have much more responsibility on Mother's Day.

At the same time, the school calendar has impressive aspects, such as the dialogue between teachers and students. During recent decades students have been given a significant role in designing feasts or festivals. Part of the school calendar is organized by students, such as Teacher's Day, Ribbon Bow Day (tutipäev), students' initiation ceremony (hazing), April Fool's Day, Valentine's Day, St. Martin's and St. Catherine's Day, Christmas party, and school balls.

\section{Acknowledgements}

The article was supported by research grant of the Estonian Literary Museum EKM 8-2/20/3, and by the Centre of Excellence in Estonian Studies (TK 145) through the European Regional Development Fund. 


\section{Notes}

1 In 1992 and 2007, students were encouraged to give their answers in dialect, yet there were few respondents. Russian-language students' folklore was collected in 1993 and 2008 (only the pilot project); in 2018 students from Russian-language schools were asked to answer along with Estonians, but they were allowed to give answers in Russian. Russian school folklore campaigns deserve a separate investigation and are not discussed in this article.

2 The leading group included Mare Kõiva, Anu Vissel, Astrid Tuisk, Eda Kalmre, and Ants Johanson. To analyse the data, Arvo Krikmann, Mall Hiiemäe, Karin Ribenis, Kadri Peebo-Tamm, Pille Kippar, Art Leete, Mare Kalda, Kadi Sarv, Eda Tagamets, Marju Kõivupuu, Maarja Villandi, and Sirle Pent joined the group. Part of the team members (e.g. Tagamets) were still university students and Maarja Villandi, one of the best collectora high schooler. A year later Russian children's folklore collection continued (Kõiva \& Vissel 1993). The initial collection work was based on the experience of Leea Virtanen, the Finnish scholar (Virtanen 1970). However, the methodology, selection of schools, communication, preparations for the analysis of the material and research, as well as finding sponsors for the prizes for children remained the task of our team.

3 The recognized written forms were hand-written memory rhyme albums, songbooks, incantations; unfortunately, notebooks containing legends and anecdotes were left aside due to the applied criteria. The problems of authenticity were raised by the research group of short forms and they were formulated by A. Krikmann.

4 It was even more visible in 2018 (cf. Kõiva 2020).

5 There are about 5,000 Catholics in Estonia and a few Catholic schools, which have an about 20-years' tradition. These schools have a good reputation and media representation, and strong church orientation (Kõiva 2016; EFITA, F01-021-006-0003). Orthodoxy spread during the conversion movement in the 1840s. The last decades of the $19^{\text {th }}$ and the beginning of the $20^{\text {th }}$ centuries was the period of strong Russification, which changed the attitude towards Orthodox Church. The initial religious conversion movement was related to the hope for economic mitigation, and it has also been interpreted as a protest movement against Baltic Germans' superiority in church. A more vehement conversion took place in the periphery and in southern Estonia, and this particular spread persisted also later on.

6 The anniversary of the Tartu Peace Treaty has been a national holiday only since 2009 , although it is a highly significant event in terms of the establishment of the state. As was mentioned above, these celebrations are especially well rooted in Tartu and 
also in a few other cities, where schools organize festive meetings and all-city quizzes; however, there are also schools in which this day is only remembered in history classes. 7 Victory Day marks the Battle of Võnnu (Cēsis). The holiday has been celebrated since 1934 and marks the victory of Estonia in this battle against the Baltische Landeswehr on 23 June 1919.

89 May is a national holiday and a day off in all the former republics of the Soviet Union, except for the Baltic states.

9 Kalevipoeg is a monument to the War of Independence, which was dedicated to the soldiers who lost their lives in this war. In 1950, the monument was taken down by the Soviet authorities. Kalevipoeg is the main character in the Estonian national epic. In 1952, a monument to F. R. Kreutzwald, the author of the epic Kalevipoeg, was erected at the same location. The monument of Kalevipoeg was restored in 2002. Throughout the Soviet period people recalled the monument of Kalevipoeg as an important symbol of independence.

10 The biggest deportations took place on 25 March 1941, during 1945, on 14 June 1949.

\section{Sources}

EFITA - Scientific archives of the Department of Folkloristics, Estonian Literary Museum, collection KP2018 (School lore 2018).

Skriptoorium - Digital tool of the Department of Folkloristics, Estonian Literary Museum, digital data of the 1992 and 2007 school lore collections.

\section{References}

Annom, Inge \& Tuisk, Astrid 2020. Viis ritta. Meie kooliaja mängud 1990. aastate alguses [Five in the Row. Games of Our School Time at the Beginning of the 1990s]. Tartu: ELM Scholarly Press.

Assmann, Jan 2011. Communicative and Cultural Memory. In: P. Meusburger \& M. Heffernan \& E. Wunder (eds.) Cultural Memories. Knowledge and Space (Klaus Tschira Symposia), Vol. 4. Dordrecht: Springer, pp. 15-27.

Eisen, Matthias Johann 1931. Meie jõulud [Our Christmas]. Tartu: Eesti Kirjanduse Selts. Gergova, Lina 2013. The High-school Graduation Ball in Bulgaria. In: Arūnas Vaicekauskas (ed.) The Power of the Mask. The Ritual Year 5. Kaunas: Vytautas Magnus University, pp. 79-89. 
Hardmann, Charlotte 2001. Can There Be an Anthropology of Children? Childhood, Vol. 8 (4), pp. 501-517. DOI: 10.1177/0907568201008004006.

Harro-Loit, Halliki \& Vihalemm, Triin \& Jõesalu, Kirsti \& Seljamaa, Elo-Hanna 2020. Mapping celebration practices in Estonia: which days of importance actually influence societal rhythms? In: Anu Kannike \& Katre Pärn \& Monika Tasa (eds.) Interdisciplinary Approaches to Culture Theory. Tartu: Tartu University Press, pp. 284-328.

Hiiemäe, Reet 2002. Uued suunad rahvaluulekogumises alates 1980. aastatest Eesti Rahvaluule Arhiivi laekunud ainese põhjal. Kogumisest uurimiseni [From Collecting to Research]. Artikleid Eesti Rahvaluule Arhiivi 75. aastapäevaks. Eesti Rahvaluule Arhiivi Toimetused 20. Tartu: Eesti Kirjandusmuuseum, pp. 280-293.

Hiiemäe, Reet 2018. Collecting Action “School Lore 2018” Exceeded All Expectations. Folklore: Electronic Journal of Folklore, Vol. 73, pp. 180-189.

Hirschenfeld, Lawence 2008. Why Don't Anthropologists Like Children? American Anthropologist, Vol. 104 (2), pp. 611-627. DOI: 10.1525/aa.2002.104.2.611.

Hirschenfeld, Lawence 2013. The Myth of Mentalizing and Primacy of Folk Sociology. In: M. R. Banaji \& S. A. Gelman (eds.) Navigating the Social World: What Infants, Children, and Other Species Can Teach Us. Oxford: Oxford University Press, pp. 101-106. https://drive.google.com/file/d/0BxGMpl_ DepzRVHp3bjI2MFh0NlE/view.

Hugoson, Marlene 2013. Embracing a Virtual Reality: The Masking and Guising of Star Trek Enthusiasts. In: Arūnas Vaicekauskas (ed.) The Power of the Mask. The Ritual Year 5. Kaunas: Vytautas Magnus University, pp. 30-40.

Kalmre, Eda 1995. Koolipärimuse kogumisvõistluse küsitluskava [A questionnaire for the school lore competition]. In: Kõiva, M. (ed.) Lipitud-lapitud: Tänapäeva folkloorist 1 [Contemporary Folklore 1]. Tartu: EKM Teaduskirjastus, pp. 325-330.

Kalmre, Eda 2003. Kuuldust-nähtust. Tänapäeva folkloorist 4 [Contemporary Folklore 4]. Tartu: EKM Teaduskirjastus.

Kalmre, Eda (ed.) 2010. Tulnukad ja internetilapsed. Uurimusi laste- ja noortekultuurist [Aliens and the Internet Children. Studies about Contemporary Children and Youth Culture]. Tartu: ELM Scholarly Press.

Kõiva, Mare (ed.) 1995a. Lipitud-lapitud: Tänapäeva folkloorist 1 [Contemporary Folklore 1]. Tartu: EKM Teaduskirjastus.

Kõiva, Mare 1995b. Koolipärimuse kogumise ja kogumiku saateks [About the Collection of School Lore and the Current Selection of Papers]. In: Mare Kõiva (ed.) Lipitud-lapitud: Tänapäeva folkloorist 1 [Contemporary Folklore 1]. Tartu: EKM Teaduskirjastus, pp. 331-334. 
Kõiva, Mare (comp.) 1996. Contemporary Folklore. Tartu: Eesti Keele Instituut.

Kõiva, Mare (ed.) 2000. Meedia. Folkloor. Mütoloogia [Media, Folklore, Mythology]. Tartu: Eesti Kirjandusmuuseum.

Kõiva, Mare 2004. Koolikalender [School Calendar]. In: Mare Kõiva \& Taive Särg \& Vesik, Liisa. Berta: Eesti rahvakalendri tähtpäevade andmebaas [Berta: The Database of Folk Calendar Holidays]. Tartu: Tiigrihüpe; Estonian Literary Museum.

Kõiva, Mare 2006. Easter in Estonia. In: George Mifsud-Chircop (ed.) The Ritual Year. Proceedings: First International Conference of the SIEF Working Group on the Ritual Year, Malta, 20-24.03.2005. Malta: University of Malta Junior College Msida, pp. 340-361.

Kõiva, Mare 2014. Calendar Feasts: Politics of Adoption and Reinstatement. Through the Ages. Time, Space and Eternity. Sator 13. Tartu: ELM Scholarly Press, pp. 7-40.

Kõiva, Mare (comp., ed.) 2014. Maailm ja multitasking [World and Multitasking]. Tartu: EKM Teaduskirjastus.

Kõiva, Mare 2016. Поклонничеството в секуларизираното общество - възраждане и особености [Pilgrimage in the secularized society - revival and specifics]. Български фолклор, XLII (1), pp. 64-77. (In Bulgarian.)

Kõiva, Mare 2020. Heategevus- ja solidaarsusmeditsiini problemaatikast Eesti näitel [Charity and solidarity medicine problems: The Estonian case]. Mäetagused, Vol. 78, pp. 43-64.

Kõiva, Mare \& Kuperjanov, Andres 2014. The View from the Migrant's Window. Interactions of the Estonian and Swedish Ritual Year. In: Dobrinka Parusheva \& Lina Gergova (eds.) Migrations. Sofia: IEFSEM-BAS. The Yearbook of the SIEF Working Group on The Ritual Year, Vol. 8, pp. 193-215.

Kõiva, Mare \& Vissel, Anu 1993. Koolipärimus [School lore]. Pro folkloristica 1. Tartu: Eesti Teaduste Akadeemia.

Mardosa, Jonas 2016. Lietuvos valstybès atkūrimo ir nepriklausomybės šventės [Holidays of the Restoration of the Lithuanian State and the Restoration of Independent State]. In: Rasa Paukštytė-Šaknienė \& Žilvytis Šaknys \& Jonas Mardosa \& Irma Šidiškienè Šventes šiuolaikineje vilniečiu šeimoje. Vilnius: Lietuvos istorijos institutas, pp. 105-121.

Niemi, Pia-Maria \& Kimanen, Anuleena \& Kallioniemi, Arto 2019. Including or Excluding Religion and Worldviews in Schools? Finnish Teachers' and Teacher Students' Perceptions. Journal of Beliefs and Values, Vol. 41 (1), pp. 114-128. https://doi.org/10.1080/13617672.2019.1617628.

Papathomas, Grigorios D. \& Palli, R. P. \& Matthias, H. 2002. The Autonomous Orthodox Church of Estonia. $r$ L'Eglise autonome orthodoxe d'Estonie. NOMOKANONIKH $\mathrm{BIB} \Lambda \mathrm{IO} \Theta \mathrm{HKH}$ 11. Athena: Epetasis. Approche historique et nomocanonique. 
Õunapuu, Piret 2001. Pühad ja kombed [Holidays and Customs]. Tallinn: Tänapäev.

Paukštytė-Šaknienè, Rasa 2018. Vilniaus ir Sofijos gyventojų šeimos šventès [Festivals in Families in Vilnius and Sofia]. Lithuanistica, Vol. 64 (1), pp. 58-72. https:// doi.org/10.6001/lituanistica.v64i1.3696.

Riley, Kathleen C. \& Paugh, Amy L. 2019. Poverty and Children's Language in Anthropolitical Perspective. Annual Review of Anthropology, Vol. 48, pp. 297315. http://dx.doi.org/10.1146/annurev-anthro-102218-011224.

Šaknys, Žilvitys 2015. Užgavènès: A Rural and Urban, Religious, Socialist, and Lithuanian Festival of Shrovetide. Folklore: Electronic Journal of Folklore, Vol. 60, pp. 105128. http://dx.doi.org/10.7592/FEJF2015.60.shaknys.

Vaher, Triinu 2019. Jõulud - statistika [Christmas - Statistics]. Prohvet. November. https://katoliku.edu.ee/esileht/hariduskeskus/ajaleht-prohvet.

Vaicekauskas, Arūnas (ed.) 2015. The Power of the Mask. The Yearbook of the SIEF Working Group on The Ritual Year 5. Kaunas: Vytautas Magnus University.

Vesik, Liisa 2015. Valentine's day is friendship day in Estonia. $12^{\text {th }}$ SIEF Congress Zagreb 2015. Utopias, Realities, Heritages: Ethnographies for the $21^{\text {st }}$ century, Abstracts. SIEF: Zagreb, p. 130.

Vesik, Liisa 2016. The Evolution of Valentine's Day in Socialist and Post-Socialist Times. In: Emily Lyle \& Guzel Sotlyarova \& Irina Sedakova \& Nina Vlaskina (eds.) The Ritual Year 11. Traditions and Transformations. Kazan-Moscow: T. 8, Moscow, Russia. The Ritual Year. The Yearbook of the SIEF Working Group on The Ritual Year 11, pp. 282-294.

Voolaid, Piret 2006. Elevernas folktradition på de före detta kustsvenska områdena i Estland - på Nuckö och på Ormsö - våren 2006 [Children's Lore in Estonia, Noarootsi and Vormsi, 2006]. In: Nina Smeds (ed.) Det var en ko och det var poängen. Åland: Nordens Institut på Åland, pp. 188-195.

Voolaid, Piret 2007. Children and Youth Lore: Innovations and Traditions in Contemporary Society. Folklore: Electronic Journal of Folklore, Vol. 35, pp. 149-152.

Voolaid, Piret 2020. Naljapäeva vanasõna: "Ega naer nahka riku, ega tühi jutt tükki võta." EV 7133 - Piret Voolaid, 1. aprill 2020 [Laughter doesn't ruin your skin and the rumor doesn't take the pieces off your body. Proverb for 1 April]. Folkloristika osakonna loengud. http://www.folklore.ee/rl/fo/loeng/naljapaev_vanasona.mp4.

Mare Kõiva, PhD, Leading Professor, Head of the Department of Folkloristics at the Estonian Literary Museum, Tartu, Estonia. She is the Head of the Center of Excellence in Estonian Studies and the Editor-in-chief of the 'Folklore: Electronic Journal of Folklore' (founded 1996) and Mäetagused (1996-). Her main area of the field reasearch is Estonia, Bulgaria, Byelorussia. Her research focus 
Mare Kõiva, Kristina Muhu

is on incantations and folk healers, folk religion, Estonian diaspora, mythology and contemporary folklore.

Kristina Muhu is MA student at the Institute of Mathematics and Statistics at the University of Tartu. She works at the Centre of Excellence in Estonian Studies from 2018. 